\title{
Curatorship in the Art Field between Gallery Management and Cultural Marketing
}

\author{
Vincentziu PUSCASU ${ }^{\star}$
}

\begin{tabular}{l}
\hline \multicolumn{1}{c}{ A R T I C L E I N F O } \\
\hline Article history: \\
Accepted July 2020 \\
Available online August 2020 \\
\hline JEL Classification \\
M13, Z10, Z11 \\
Keywords: \\
Contemporary art, Curatorship, Art \\
gallery management, Cultural \\
marketing
\end{tabular}

\section{Introduction}

Far from being considered only as a "beautiful and elitist" field, the world of contemporary arts is nowadays a living stage on which controversial social realities and contrasting political ideologies are appearing. The management of a cultural event requires, more and more, not only the skills of an art dealer of the twentieth century, but also knowledge of management and cultural martketing grafted on a solid theoretical artistic foundation. From this perspective, curatorship is the perfect space for the interaction of these dimensions.

The effective action of curating the artistic corpus of contemporary art involves the interpretation of the series of works that are the object of the exhibition, in order to evoke some suggestive or representative particularities. It also refers to the spatial arrangement of the works. This process involves the creation of a communicating network (indexical features) based on curatorial research conducted along with the artist (when possible). The end of the millennium comes with a new positioning of the visitor in terms of the exposed artistic corpus. As Rosalind Krauss stated in her 1990 essay, the institutions that exhibited contemporary art (whether it was about museums or private art galleries) are beginning to face the "dematerialization and decorporalization effect" specific to the exhibition approaches of the Fluxus movement (Krauss, 1990). This phenomenon has been linked to the emerging ideological waves associated with the trend of globalization of perceptual typologies and cultural constructs from which they emerge. As a result, art museums are oriented towards an experimental typology, which involves a change in the role and responsibilities of the staff responsible for valuing and "explaining" the work of art. In this way the curator and the art critic acquire extended prerogatives, entering the paradigm of the artistic decision-making supercourt.

\section{Literature review}

The issues that curatorial practice raises are studied by the specialized bibliography of several disciplines, such as aesthetics, art history, art criticism, axiology, etc. Famous authors such as Martinon, Groys, Jeffery, Bishop, Szeemann or OBrian have contributed to the establishment of a humanist curatorial theory, but the positivist perspective on the phenomenon prevails. The interpretation of the phenomenon from the quantifiable perspective of economic disciplines, management, or even practical exhibition implementations has not been sufficiently deepen. Consequently, my study is based on the interpretation of 
several curatorial theories proposed by authors such as Terry Smith, Hans Ulrich Obrist, Claire Bishop, Celina Jeffery and Harald Szeemann, that I relate to the gallery exhibition activity. This article is a synthesis of my own version of interpretation of these theories, respectively of the way in which they can be included in the management of art gallery, respectively in the extended spectrum of cultural management. The methodology of this research provides a brief theoretical investigation on curatorial acts, corroborated with factual data taken from the exhibition practice of the period 2017-2018 in Bucharest. a Metodologia cercetării de față prevede o scurtă investigație teoretică asupra actelor curatoriale, coroborată cu date factuale prelevate din practica expozițională a intervalului 2017-2018 din municipiul București. We also attached a case study on the "New Senses" project, in which we conducted a different management strategy from what is commonly practiced on the local art scene.

\section{Theoretical framework}

With the development of creation typologies specific to contemporaneity, the artistic object begins to have increasingly complex characteristics and meanings, getting rid of its aesthetic features until dissolution. Using a wide range of signification, this phenomenon determined the modification of the curatorial activity powers, an authority that deals with the promotion and dissemination of artistic acts to the public. The curatorial institution diversifies, producing a critical meta-discourse, an ideatic suprastructure extracted from the register of artistic authenticity, according to which the exhibition paradigms were subsequently modeled (Bishop, 2007). Taking into account that the curatorial activity is related to the exhibition management (Greenberg et al. 1996; Obrist 2011), respectively to the fact that the perceptual specificities of the art object tend towards the eventful, spectacular and experiential directions (Vanderlinden, Filipovic 2005; Groys 2008), the need to approach curatorial acts from a systemic perspective (managerial type) becomes implicit. Although the curatorial phenomenon has existed since the configuration of the first art collections (Pomian, 1990), its management and conduction in a coherent and authentic way begins in the 600, along with artistic events curated in the Documenta series (Szeemann, 2007; Vanderlinden, Filipovic , 2005).

The curatorial activity supposes the capitalization of works of art in the context of an exhibition. This can be done by means of using some operational parameters, with the help of which the curator synthesizes a general concept, which he subsequently places in the designated contexts (Szeemann, 2007; Ferguson, 1996; Acord, 2010). The process meets the significant content that the artist proposes, enhancing the dialogical elements and the relational perspective of the audience (Martinon, 2013; Smith, 2012).

\section{From museum management...}

Unlike art museums in Western Europe and the United States, within the exhibition management of institutions dealing with contemporary art in Romania, the phenomenon of transformation and coming to the public (in terms of strategy) occurred quite late (Opriș 2008). Many of the Romanian art museums neglected the possibility of converting the institution into a real cultural hub, with the role of social aggregator and opinion maker (MacLeod, 2012). Moreover, many art institutions kept the rigid structure of the role and functions of a museum, even if the art they exhibited was not eloquently highlighted. On the other hand, the distribution of the museum's organizational chart remained unchanged and the curator was in charge only of administrative, organizational or research duties (Nicolescu, 1975; Florescu, 1994; Opriș, 2008; idem, 2000). That is why, the Romanian contemporary art scene has experienced a significant decline during the last decades. Furthermore, by neglecting the managerial aspects required by the curatorial discipline we came to neglect the cognitive-didactic particularities of the art exhibitions.

Besides the institutional aspects of the museum's management strategy, the adaptation of the types of discourse and the curatorial implementation of the exhibitions hold an important position. This can facilitate the inclusion of the public and its representativeness in terms of cultural specificity. Although the first actions to restructure the museum (and gallery) management can be identified since the '20s (Lorimer, 1927), these features appeared very late and only partly in Romanian art museums (except for National Museum of Contemporary Art, Bucharest). Most often the dynamics of this phenomenon can be noticed in private art galleries, in artistic residences or in associations and non-governmental organizations . In Bucharest, only Museum of Recent Art, National Museum of Contemporary Art (and rarely The National Museum of Art of Romania) apply authentic curatorial strategies, adapted to the typical pattern of contemporaneity. 


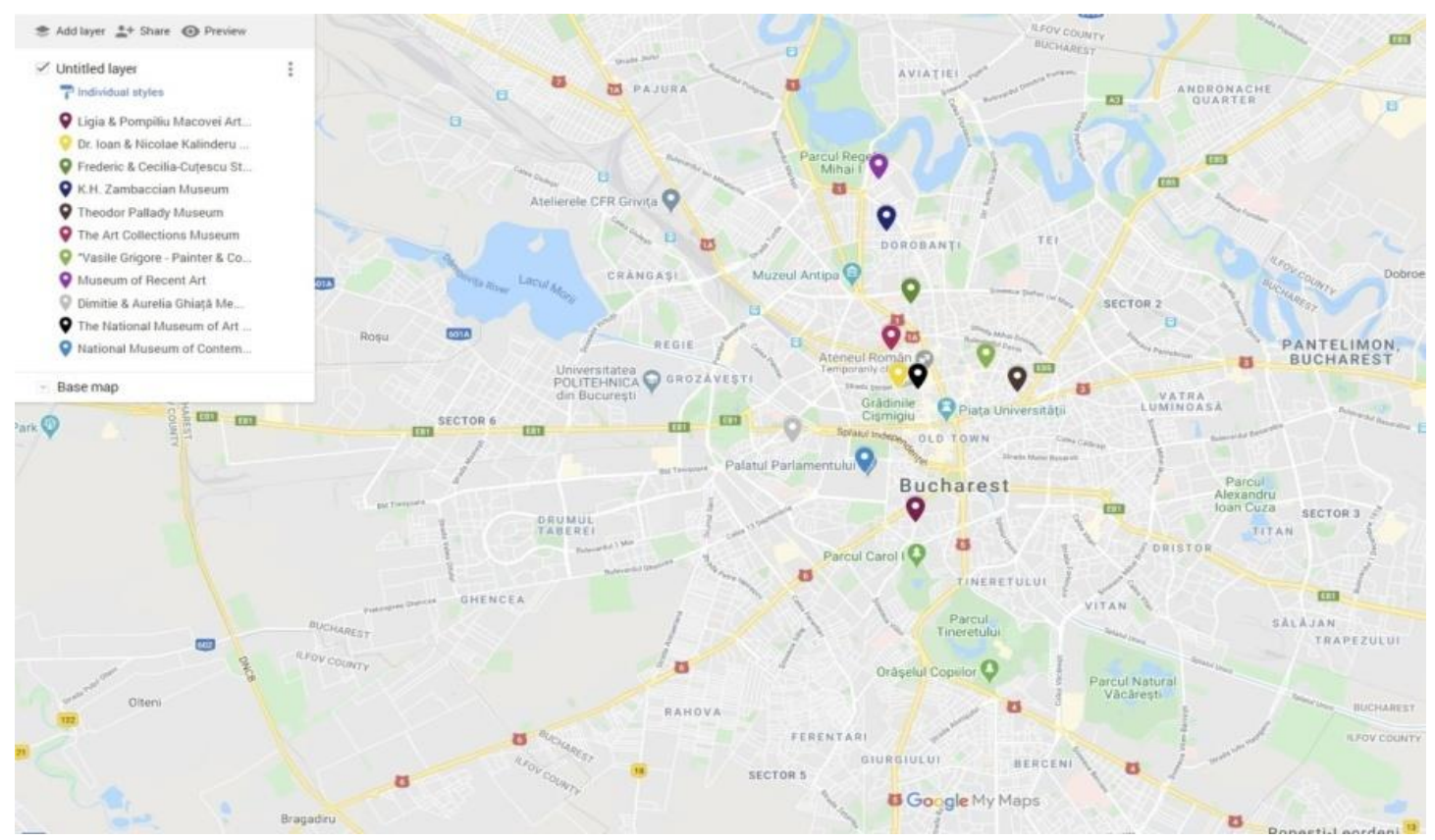

Fig. 1. Distribution of art institutions in Bucharest

\section{5. ... to gallery management}

The curatorial flexibility of the exhibition of contemporary art in a private space is greater than the curatorship inside the institutional context. Therefore, my proposal is delivered in the context of a private art market generated mainly by the emerging phenomenon of shopping centers. In the light of the activity it performs, the gallery facilitates the perceptual experience of the aesthetic object to the public (Berton et. al. 2012). Moreover, in the shopping gallery, of the art object can be exploited from an economic point of view. The methodology of working out the exhibitions and the curatorship in art galleries are similar to the museum-type curatorship, but this one sets out the art object differently, because one of the purposes of the exhibition in the shopping centre is sale.

In Romania, many of the private art galleries have reused or reconverted old buildings, thus actively contributing to the diversification of the architectural and cultural specific features of urban areas (Criticos et. al. 2010). Following a field research undertaken during 2017, we visited a series of art galleries in Bucharest, to examine how the curatorial means are adapted, in order to match the interior architecture with the discursive specificity of the exhibited art objects.

We chose only galleries taking part in the NAG (White Night Of The Art Galleries) 2017 project, choosing exhibition spaces with private equity. The result of the research pointed out that, in most cases, they used architectural spaces that were originally intended for residential use (fig. 2). In Bucharest, one can see an agglomeration in the central area of the city, thus we understand that the ideal location of an art gallery is near heavy traffic routes, as they are easier to locate.

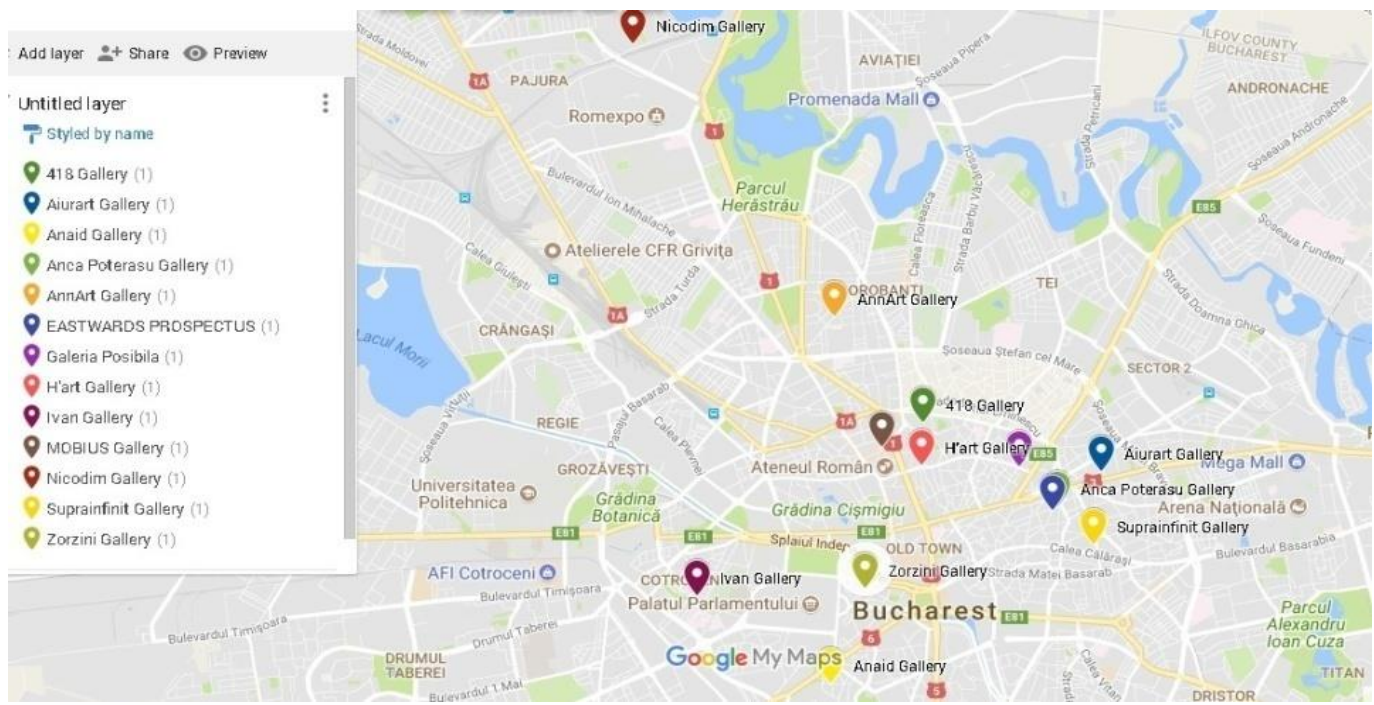

Fig. 2. Distribution of private art galeries in Bucharest 


\section{Case study - The "Sensuri Noi" Project}

During 2017, I decided, together with a co-worker, to set up a centre for the promotion of arts and culture, an institution in which we were to work for an indefinite period of time. At the beginning of the project, the activity was focused on two major areas: visual arts and theatre. My duties involved identifying some young artists and promoting their creation, by curating some temporary exhibitions. At the same time, these events had to be correlated with theatre performances, the two arts intertwining around a preestablished concept. The advantage of such an approach was the possibility of stimulating the consumption of contemporary art, respectively the increase of the perceptive experience in theatre performances. Two distinct expressive ways revolving around the same subject were delivered to the audience of both theatre and contemporary art. One of the purposes of the "Sensuri Noi” gallery was to keep a diverse and constant audience throughout the events. This purpose occured asa a result of studies and previous curatorial experience that allowed me to notice that art galleries face an unbalanced distribution of visitors. To be specific, there is a maximum point, to be found on the first day of the exhibition (the opening day), where we witness a very large number of visitors, followed by a considerable decrease after on. A targeted analysis on two events of the same artist (Induced in Industrialization, from February 7 to March 6, 2017, organized at Galateea Contemporary Art Gallery, Bucharest; respectively Angular Spheres, from May 13 to May 25, 2015, organized at Minerva Galleries in Cluj Napoca) whose curator I was, reveals the decrease until disappearance of visitors for the exhibition the days after the opening (Fig.3).

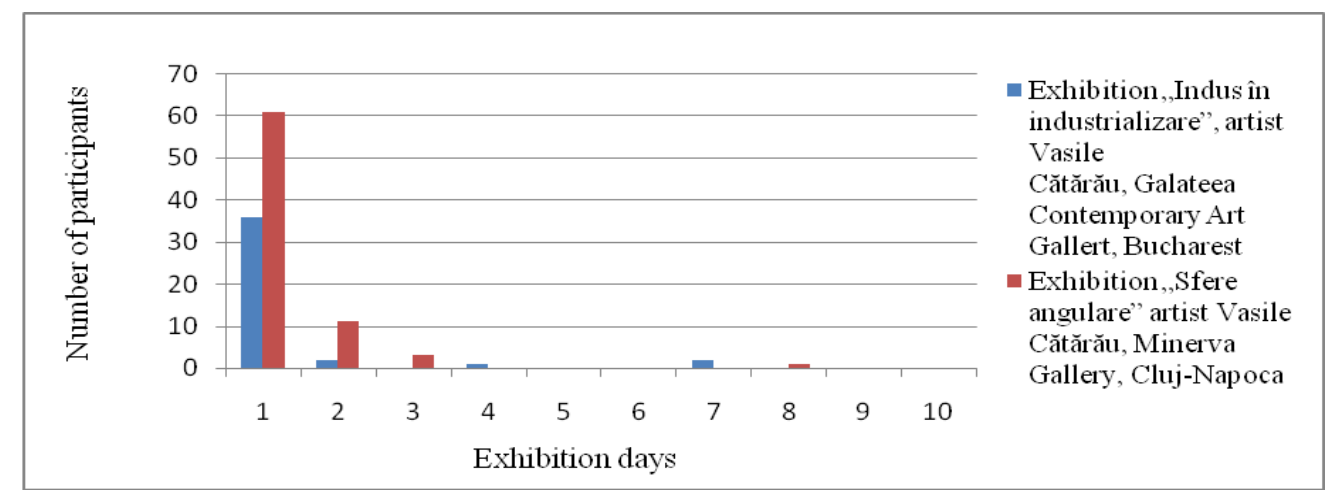

Fig. 3. Public attendance in the exhibitions Induced in industrialization and Angular spheres

The phenomenon is present in all art galleries, as they face a real incapacity to attract the public beyond the opening day program. We could claim that this failure is due to a series of local sociologic factors, but it would be a hasty generalization. The gallery owners blame the small number of public interested in conteporary art, the difficulty to catch its interest in the absence of "proceedings" (absolutely necessary for such events) and even the inefficiency of the mass media promotion and dissemination systems. It should be mentioned that the museums don't face the same problem, as these institutions acquire the public due to their prestige and permanence of their activity. When we outlined the structure and the way of functioning of Sensuri Noi Gallery we took this particularity into account. That is why I intended to have a relatively constant flow of visitors during the exhibitions. Moreover, I intended to remove the "protocol" element, by imposing an entry fee for the public. Obviously, these measures could have been considered as the perfect recipe for failure, but the reality was different. On the occasion of the exhibitions "Excuse me, is it yours this little animal with four mouths?" - artist Mădălina Panainte, new media art, respectively "Bucharest - fragments" photographer artist Vincentziu Pușcașu, we could verify the results of the association of the exhibition event with the theatrical one, as a new formula of the gallery marketing strategy (Fig.4). The number of participants was high throughout the exhibitions, in which I had both the role of curator and that of gallery owner and organizer.

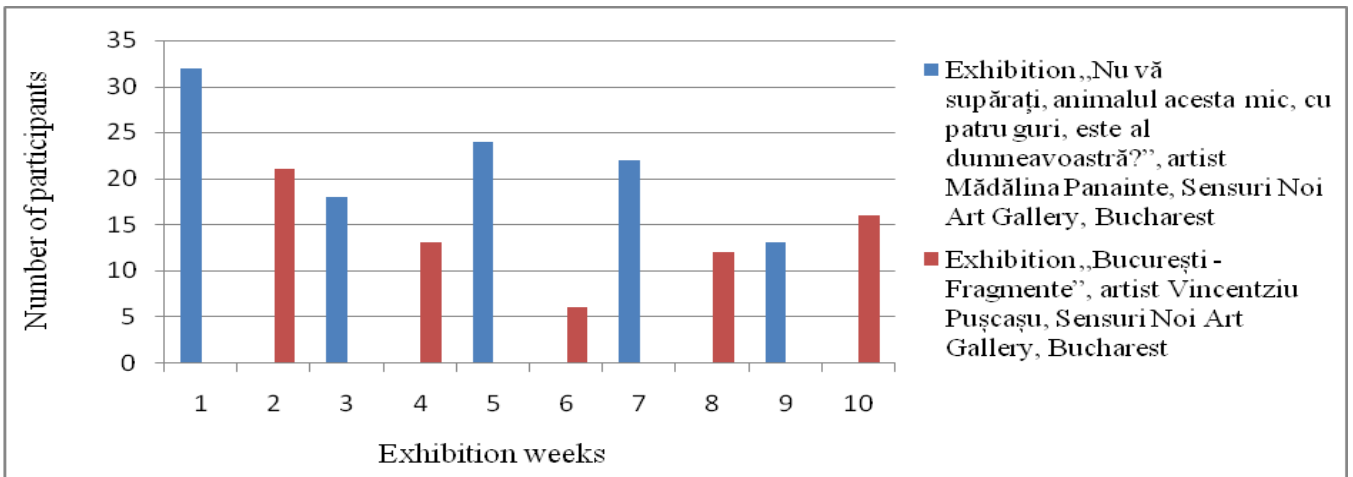

Fig.4. Public attendance to the exhibitions “Excuse me, is it yours this little animal with four mouths?” and „Bucharest - Fragments” 
The formula involved the exclusion of the opening day and its replacement with series of weekly exhibitions at the same time with the dates of the theatre performances. Thus, the public got a versatile visual experience - theatre performance and art exhibition. This approach allowed the activity to be carried out over a longer extent of time, simultaneously achieving a firm and active involvement of the public. The feedback was positive, as the association was unique, and the forms of expressing the conceptual element were diversified. The immersive and unique character of the presentation are given by the fact that the events took place in the same architectural space.

\subsection{Staging the curatorial}

It was extremely difficult to choose a location for the activity. The architectural demands required by the dissemintion of such a cultural act were not easy to fulfill. The interior space had to meet simultaneously the features of a performance hall and of an art gallery. An industrial location suitable for such an approach was identified, using the information derived from the conclusions of my dissertation paper - The architecture of the exhibition space, from theories and concepts to the practice of exhibition display in contemporary art. The principle utilitas had to be adjusted so that the indices of venustas reached the maximum values. Since the material and technical supplies did not allow an approach to the ideal frame of the white cube, we used a mixed method, designing the exhibition space in terms of versatility (Fig.5).

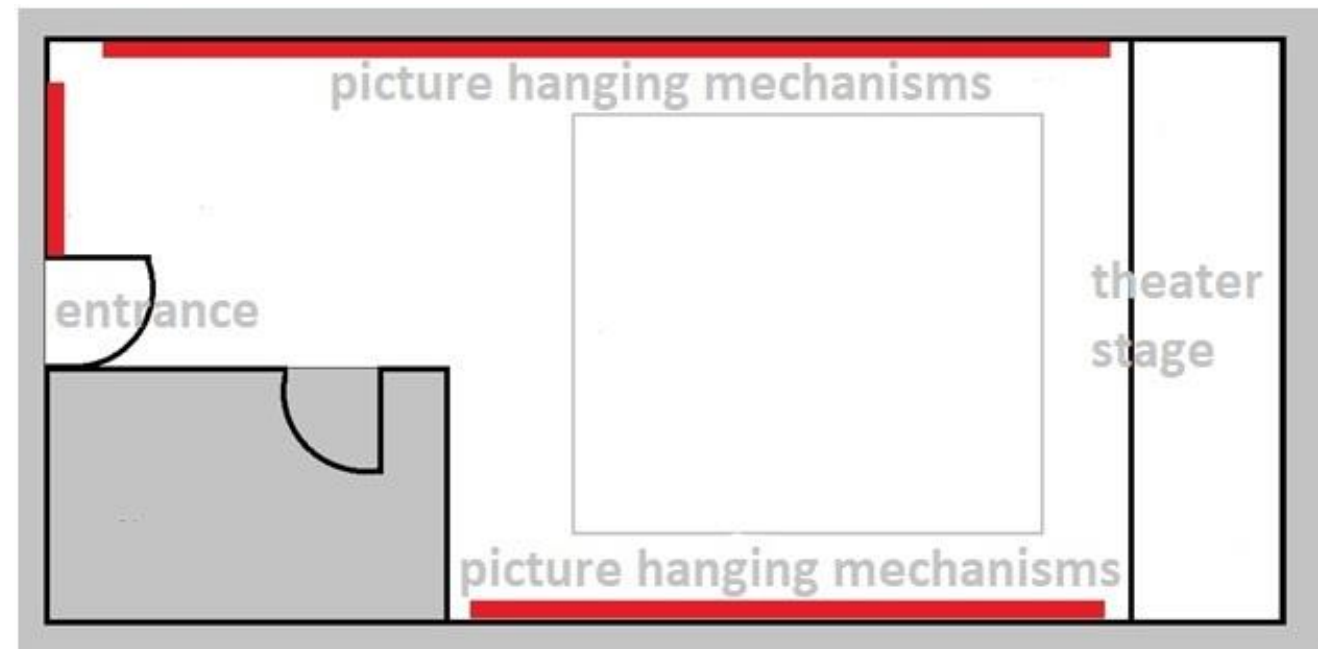

Fig. 5. The architecture of Sensuri noi exhibition space

The distribution of panels on the long sidewalls of the hall facilitated a homogenous, simplified route. Additionally, in the first phase of the event, the space in the middle was kept free, in order to offer the possibility of a panoramic perception of the exhibited works. The short sidewalls, completing the layout of the room were used for the stage, respectively for the accessways and videoprojection. Because the glass surfaces of the room were behind the stage, closing them with panels and curtains facilitated the shutdown of natural lighting. In exchange of it, we preferred to introduce passive ambient lighting systems. To illuminate the stage and the exhibition panels we used a variety of LED spotlights, respectively a light organ.

After some measurements made in art galleries and museums, we chose lighting systems that were close to the ideal values described by them. Therefore, on top of each exhibition display, we placed a $12 \mathrm{~W}$ LED spotlight. In this way, we managed to get an $120 \mathrm{~W}$ average of the dispersed light (10 individual spotlights were used), so that the works were optimally highlighted, keeping an inward environment (quite dark - for an area of 80sqm). Electricity expenses were kept at a low level, as the total consumption did not exceed domestic values. Since the gallery did not have the specific features of the white cube, the value of the light color was about 4500K (values lower than 3000 kelvins are associated with warm white light, while values above $6000 \mathrm{~K}$ are associated with cold white light). The light beam of each spotlight was adjustable, ranging (depending on the exposure) between 400 and 600 lumens.

Moreover, the range of the light beam was about $120^{\circ}$, providing a higher contrast. This aspect facilitated an optimal visual separation of the artworks from the underneath surfaceof the wall, rendering at the same time a nice ambiental dispersion of light. Another issue I had in mind concerned the angles of incidence that the light beam formed with the plan of the work. Although I could implement a perpendicular transposition, I preferred that the light interfere tangentially with the plan of the work. One of the reasons I made this option was to eliminate reflections and disturbing glow of the various displayed materials. The textual elements (museum labels, exhibition review) were placed near the works and the curatorial act included the use of videoprojection for the determination of the references.

At the exhibitions Sensuri Noi, for displaying the artworks we used modular systems anchored to the surface on the wall. They could be adjusted on height, according to their size and the type of the artistically 
displayed works. We chose a distribution of works respecting the equidistance rules, keeping a height level between $1,5 \mathrm{~m}$ and $1,8 \mathrm{~m}$ above the floor. From a methodological point of view, I tried to allign the geometrical centres (resulting from the intersection of the diagonals), by placing them in the area of a transverse axis which crossed the midpoints of clearview anatomic angles. I avoided grouping the works in clusters because the spatial architecture of the gallery as well as the large surface of the self-supporting elements allowed an extended planimetric use.

\subsection{The events}

The course of events involved a short moment for the presentation of the artworks in the exhibition, followed by the theatrical performance. The concept of the stage direction supposed the translation of the main ideas and concepts from the art exhibition in the theatrical form, and the works as a whole were made uniform, leaving the feeling of a singular, indivisible event.

As the performed plays took the forms of the theatre of the absurd, the viewer felt the visual experience as an immersion, finding difficult to distinguish the limits of the two artistic typologies (theatre and visual art). The procedure by which the artistic concepts were turned into theatrical language language relied on a detailed analysis of the image corpus in the exhibition. Starting from the the coordinates outlined by the artist, the stage director had selected the equivalent scenographic material which he later adjusted according to the favourable context of the exhibited artwork. In this way, there was a transdisciplinary communicative connection between the displayed works and the acting game. My role as a curator was to identify artists and compatible artworks that I analysed thoroughly.The ekphrastic approach was interpreted by the stage director that turned the descriptive structure into its narrative equivalent. We determined together the significant elements and the suitable lucrative means that we included in a short presentation, carried out at the beginning of the visit. The public had been informed about the expressive form chosen for our approach, then, throughout the attendance of the event, they were about to identify the conventions and the equivalences of the system. In other words, the curatorial act was appraised from a dual perspective, which transfered the meaning into the multidirectional manner of the two artistic typologies. Assesing the entire exhibition in terms of a site-specific installation, these experiments made me analyze the ways in which two environments with different ontological status can communicate, provided that they have similar ideatic content.

My interest for intermediation and ways to improve the curatorial act came long before the creation of my own gallery. However, the previous experiences and the practice in this field didn't offer me the opportunity to innovate on overall phenomena as I couldn't experiment on different corpora and contexts.

\section{Conclusion and further debates}

Since all over the world the consumption of contemporary art and the attendance at fairs or biennales becomes a common activity, included into the area of touristic activities, I consider that an analysis of strategic means and of management opportunities of the curatorial practice can lead to the development of cultural marketing phenomena. Moreover, it could be a good alternative to attract the public if we put together the artistic domains under the form of a unitary event corpus. Paraphrasing Joseph Pine, contemporaneity is marked by a different economic paradigm, a transition to what the author called "the experience economy" (Pine, Gilmore, 2011). Citing from Joseph Pine, contemporaneity is marked by a different economic paradigm, of transition to what the author called "the experience economy" (Pine, Gilmore, 2011).

Given that the curator is the facilitator of the artistic exhibition experience (Jeffery, 2015) as he provides the customization of the artistic service according to the cultural context and paradigm in which he places himself, the interpretation and the extended management of the representational act could be an excellent working tool.

In addition, Sensuri Noi project represents a possible working pattern for the generalizing integration of arts in a structure with increased economic potential. This one assumes the inner value of each type of artistic expression (theatre, visual arts, rhetorics, etc) transposing it in a complex and versatile cultural product. One of the last aims of this instrumentation is the democratic participativity and the universalized social-cultural representativity of the artistic creation in relation tot the public.

\section{References}

1. Acord, S. (2010), „Beyond the head: The practical work of curating contemporary art”, Qual Sociol, 33, Springer 447-467.

2. Berton, A; Schwarz, U; Frey, C. (2012), "Designing art exhibitions - compedium for architects, designers and museum professionals”, Berlin, Birkhauser Verlag.

3. Bishop, C. (2007), „What is a curator”, IDEA arts + society, Cluj-Napoca, Idea Design \& Print.

4. Criticos, M; Oroveanu, A; Zahariade, A.M. (2002), „Acum: spațiul public și reinserția socială a proiectului artistic arhitectural”, vol. I-III București, Editura Universitară Ion Mincu.

5. Ferguson, B. (1996), „Exhibition rhetorics: material speech and utter sense” in Greenberg, R; Ferguson, B; Nairne, S. (1996), „Thinking about exhibitions", New York, Routledge,126-137.

6. Florescu, R. (1994), „Bazele muzeologiei”, București, Centrul de Perfecționare a Personalului din Cultură și Artă.

7. Greenberg, R; Ferguson, B; Nairne, S. (1996), „Thinking about exhibitions”, New York, Routledge. 
8. Groys, B. (2008), „Art Power”, Cambridge, MA, The MIT Press.

9. Krauss, R. (1990), „The cultural logic of the late capitalist museum”, October vol. 54, 3-17.

10. Lorimer, R. (1927), „Planning art museum”, The architectural forum, vol.47, 553-579.

11. MacLeod, S; Hanks, L.H; Hale, J. (2012), „Museum making: narratives, architecture, exhibitions”, Routledge.

12. Martinon, J.P. (2013), "The Curatorial: A philosophy of curating”, London, Bloomsbury.

13. Nicolescu, C. (1975), „Muzeologie generală”, București, Editura Didactică și Pedagogică.

14. Obrist, H. (2011), "A brief history of curating”, Zurich, JRP Riniger.

15. Opris, I. (2000), „Transmuseographia”, Bucuresti, Oscar Print

16. Opriș, I. (2008), „Provocarea noilor muzeografii”, Brăila, Istros.

17. Pine, J; Gilmore, J.H. (2011), „Experience economy: past, present and future” Boston, MA, Harvard Business Review Press.

18. Pomian, K. (1990), „Collectors and curiosities, Paris and Venice, 1500-1800), Oxford, Polity Press.

19. Smith, T. (2012), ",Thinking contemporary curating”, New York, Independent Curators International.

20. Szeemann, H. (2007), „,Whith, By, Through, Because, Towards, Despite”, New York, Springer.

21. Vanderlinden, B; Filipovic, E. (2005), „The Manifesta decade - Debates on contemporary art exhibitions and biennials in Post-Wall Europe", Cambridge, MA, The MIT Press. 